Bulletin of the Seismological Society of America. Vol. 57, No. 2, pp. 277-296. April, 1967

\title{
A MTCRO-EARTHQUAKE SURVEY OF THE SAN ANDREAS FAULT SYSTEM IN SOUTHERN CALIFORNIA
}

\author{
By James N. Brune and Clarence R. Allen
}

\section{ABSTRACT}

Micro-earthquakes have been systematically recorded with magnitudes down to -1.3 at more than 60 sites along the San Andreas fault system in southern California during intervals of 2 days to 1 year, representing more than 35,000 hours of usable records. Eight trailer-mounted instruments were operated with peak gains of 4-8 million at $20 \mathrm{cps}$ with noise levels averaging about $0.1 \mathrm{mu}$ amplitude of ground motion.

Observed micro-earthquake activity varies from virtually nil along the central section of the San Andreas fault to more than 75 shocks daily in the Imperial Valley. Quietest is the 300-km segment between Cholame and Valyermo; more than one year of recording at Lake Hughes indicates an average of only one micro-earthquake within $24 \mathrm{~km}$ every nine days. Activity increases northward from Cholame toward Hollister, and southward it increases abruptly near Valyermo and continues high along major branches of the fault southeast into Mexico, with the exception of the Banning-Mission Creek fault southeast of Desert Hot Springs. Most areas where regional strain or fault creep have been demonstrated by geodetic measurements are also areas of high micro-earthquake activity. Existence of an area of minimal micro-earthquake activity within a broad region of active tectonism, and indeed along the very segment of the fault that broke in the great 1857 earthquake, suggests that short-term micro-earthquake activity is not necessarily positively correlated with long-term activity and with earthquake hazard, and in some areas the relationship may be inverse. However, areal distribution of micro-earthquake activity is grossly similar to that of larger earthquakes $(M \geqq 3)$ during the past 29 years, and in many areas micro-earthquake activity can be approximately predicted by extrapolation of 29 -year recurrence curves based solely on larger earthquakes.

\section{INTRODUCTION}

In recent years numerous investigators have used or proposed the use of microearthquakes $(M \leqq 3$ ) in studies of seismicity and tectonic activity. Many of these studies have concerned aftershock sequences, but some investigators have attempted to observe a background seismicity which could not be obviously attributed to a preceding larger shock (Asada, 1957; Isacks and Oliver, 1964; Bune, 1964). Oliver et al (1966) found a high rate of micro-earthquake activity in aftershock zones of the 1954 Fairview Peak-Dixie Valley, Nevada, earthquakes. They also observed swarms of micro-earthquakes near Reno, Nevada, but little evidence of a more-orless steady background seismicity that could not be attributed to aftershocks. They found a good correlation, however, between micro-seismicity and seismic activity since 1932. Since the San Andreas fault is one of the best known and best-exposed transcurrent faults in the world, with obvious regional tectonic importance, and 
since it has been responsible for two of the great earthquakes in the United States, the 1906 San Francisco earthquake and the 1857 Fort Tejon earthquake, it is ideally suited for study to determine the importance of micro-earthquakes and to test some of the current ideas on micro-seismicity. This study of micro-earthquakes is the first to be based on a large sample of recording time (more than 35,000 hours) and a large number of recording sites (approximately 60 ) in a distinctive tectonic environment, and thus the results are more conclusive than those of earlier studies.

In this study the term "micro-earthquake" includes, in the sense of the Japanese classification (Hagiwara, 1964) both micro-earthquakes ( $1 \leqq M \leqq 3$ ) and ultramicro-earthquakes $(M<1)$. In practice, since the rate of occurrence of ultra-micro-

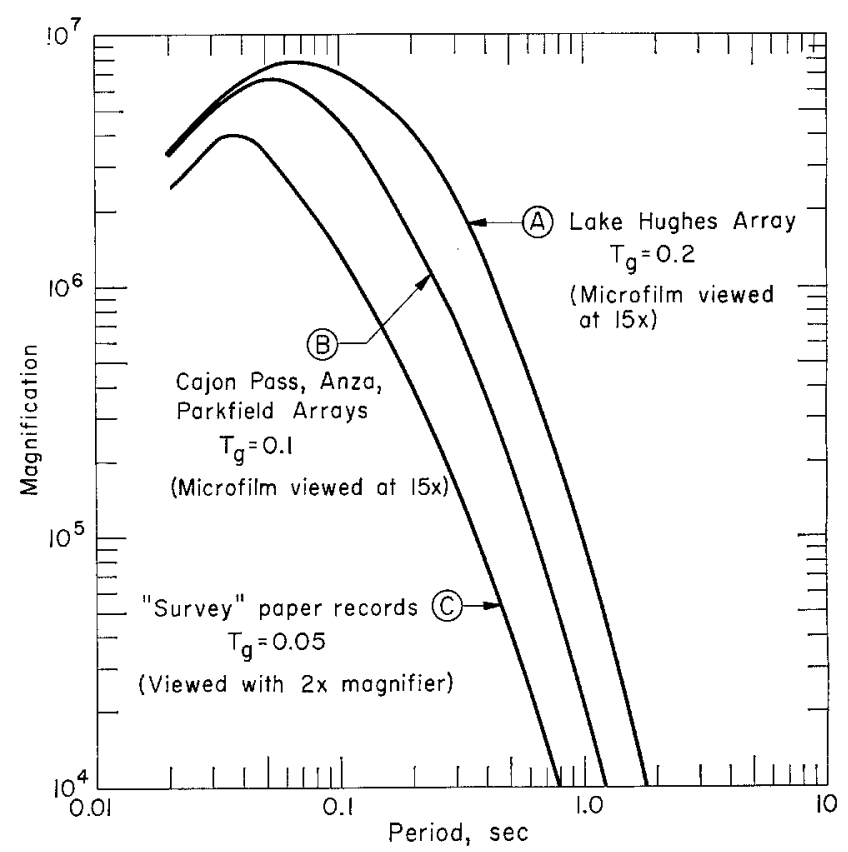

FIG. 1. Magnification curves for instruments in this study. $T_{g}=$ galvanometer period.

earthquakes is much greater than that of micro-earthquakes, nearly all the events in this study would be classified ultra-micro-earthquakes.

\section{DeSCRIPTION OF THE EXPERIMENT}

Instrumentation. The instrumentation used in the study consisted of eight movable array trailers, each having Ranger type seismometers with either 60 -day film recorders or single drum recorders in a compact trailer. The instruments are described in detail by Lehner and Press (1966). These trailers are ideally suited for research which requires frequent instrument relocation, such as the present study. The trailers have such conveniences as solid-state amplifiers, radio and clock circuitry, internal calibration, battery or powerline operation, variable magnification and filtering, as well as a high degree of mobility.

For the purposes of the survey for micro-earthquakes, the system response for 
two of the trailers was modified from that given by Lehner and Press (1966). In particular, the free period of the galvanometers was altered to $20 \mathrm{cps}$ in order to increase the high-frequency sensitivity. The corresponding amplitude response curve, used in most of the temporary sites occupied in the survey along the fault, corresponds to curve $\mathrm{C}$ in Figure 1. These trailers recorded on photographic drums. Typical records for these operating conditions are shown in Figure 2.

Subsequent to the operation of the array at Lake Hughes (response curve A), the response curves for the other six trailers were modified by changing the galvanometer period to $10 \mathrm{cps}$, giving the response curve $\mathrm{B}$ (recording on $70 \mathrm{~mm}$

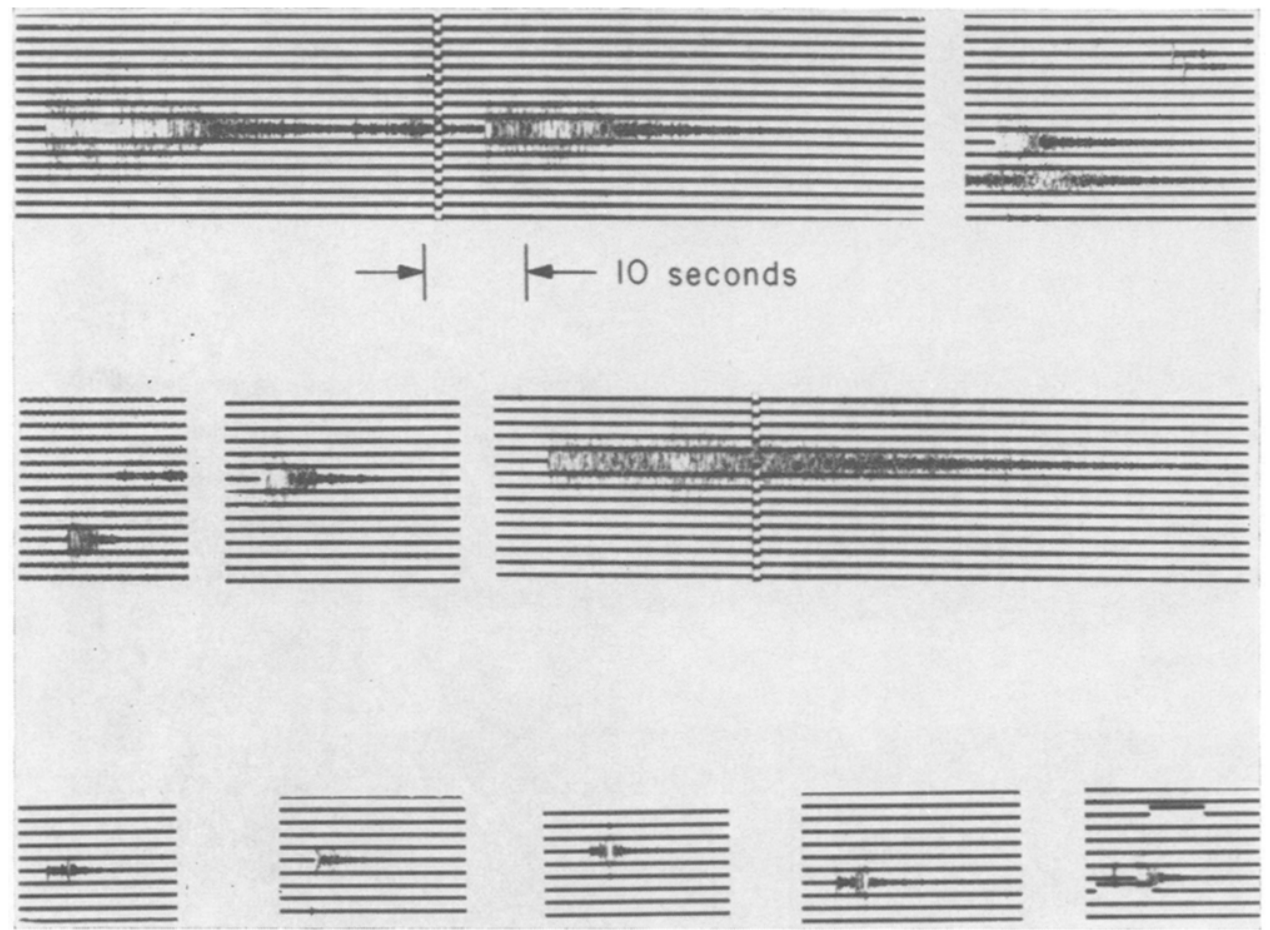

Fig. 2. Typical recordings of micro-earthquakes.

microfilm). During the operation of the array at Cajon Pass, the response of the instruments corresponded to curve B, as was also true in later operations of the array at Anza (near site 36) and Parkfield that will be described in detail in subsequent publications.

Field operation. The portable seismograph trailers were operated at sites in southern California for periods of two days or more. The sites are described in Table 1 and are shown in Figure 3. Sites were chosen at spatial intervals of about $20 \mathrm{~km}$ along the San Andreas and San Jacinto faults and at various other locations in southern California. The sites were chosen on the basis of proximity to the faults and conditions which might affect noise level. In general, bedrock outcrops, usually 


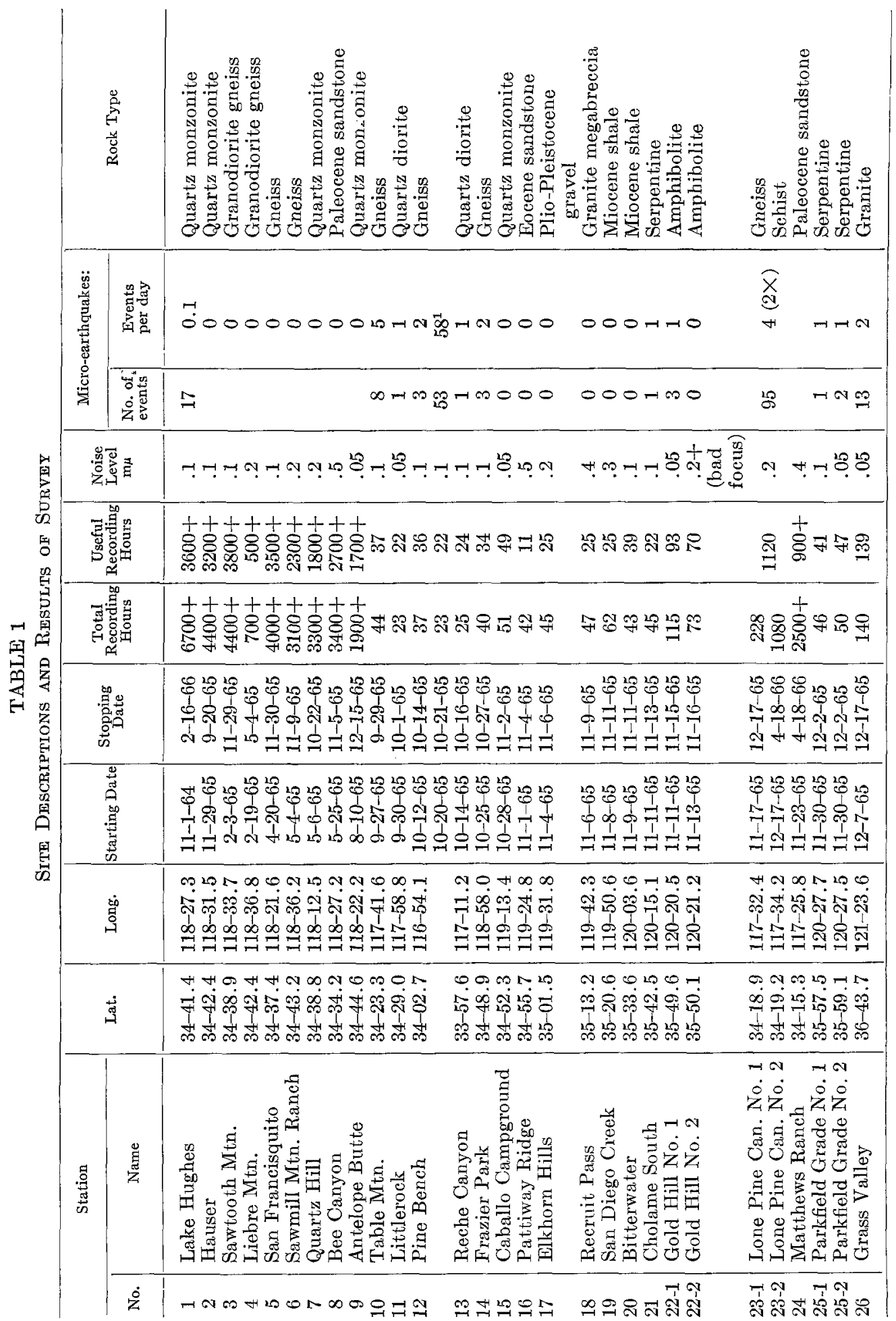




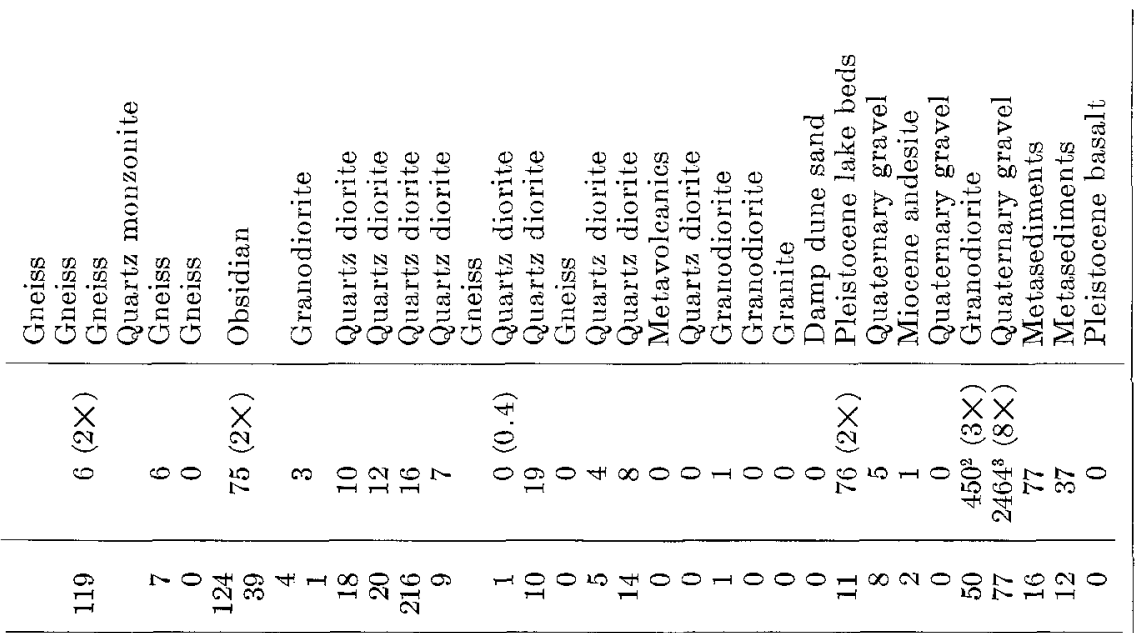

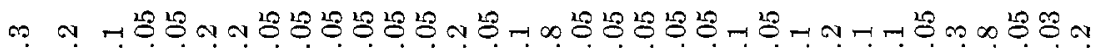

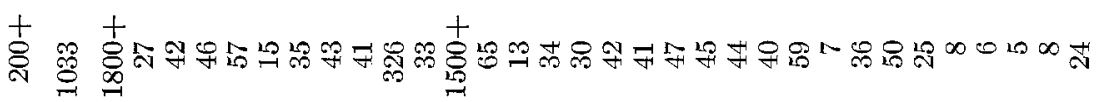

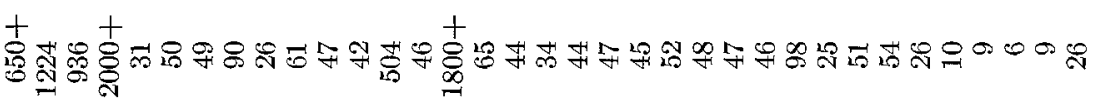

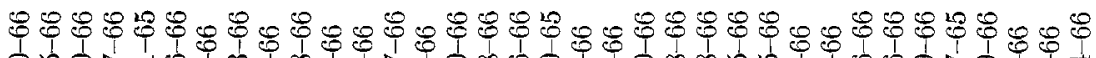
1.0.

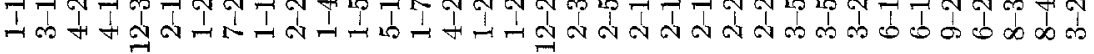

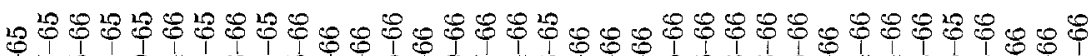

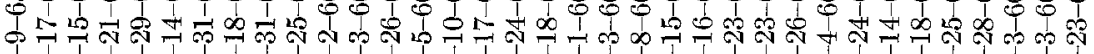

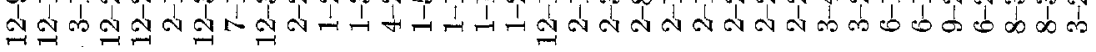

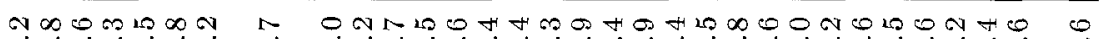
कळळ-

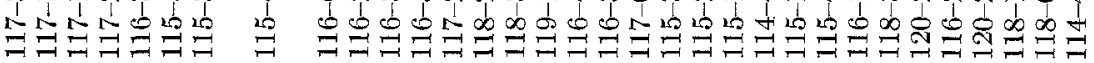

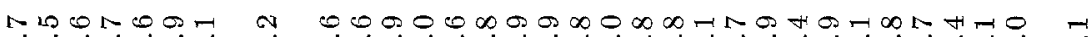

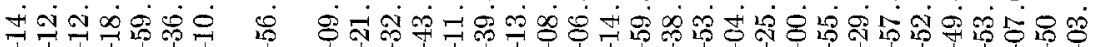

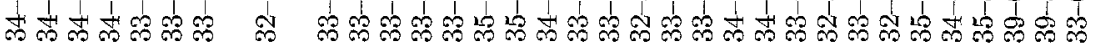

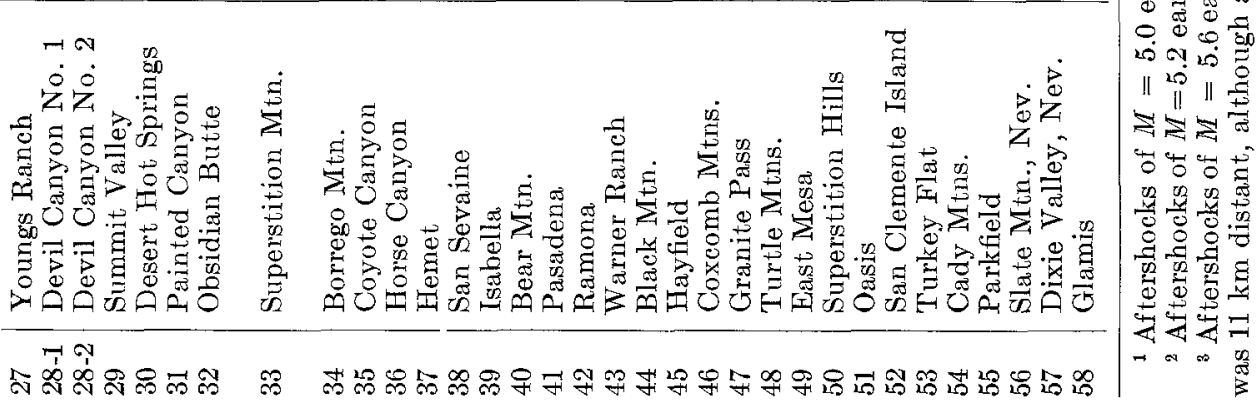


crystalline, were chosen. Obvious sources of local noise, such as trees, towns, highways and railways were avoided.

In addition to sites along the San Andreas and San Jacinto faults proper, other sites were occupied near the White Wolf fault, at Isabella tunnel, at Obsidian Butte in Imperial Valley, and along a profile of sites perpendicular to the northwesttrending San Andreas-San Jacinto system, the profile extending from near San Diego to near Needles, on the Arizona border.

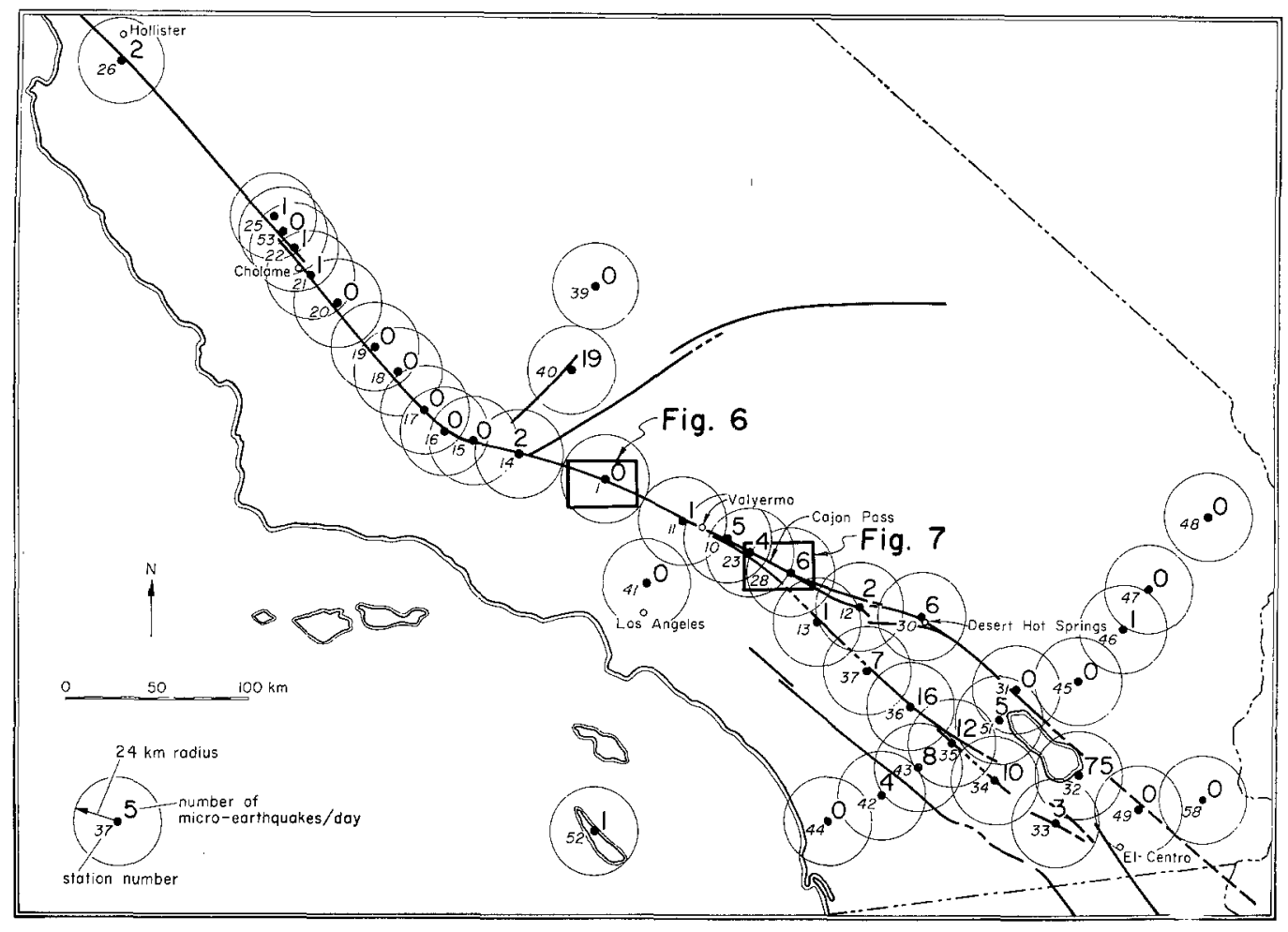

FIG. 3. Map of sites occupied in this study, numbered as in Table 1. Heavy numerals are numbers of micro-earthquakes per day within $24 \mathrm{~km}$ of station. Heavy lines are major faults.

For each site occupied, the records obtained were studied for the occurrence of micro-earthquakes with $S-P$ times of less than or equal to three seconds, corresponding to a source distance of about 24 kilometers. The total number of microearthquakes was counted and divided by the amount of noise-free recording time to give the rate of occurrence in micro-earthquakes per day. These rates, shown in Table 1 and Figure 3, were then used as the basic data for interpretation.

Sources of noise. A great variety of noise sources was encountered in this study. They can basically be divided into three types. The first type is the more-or-less continuous background noise which might be called high-frequency microseisms. The second type of noise is that which causes the trace to oscillate with such high amplitude as to obscure micro-earthquakes for periods of time generally long compared to the disturbance caused by micro-earthquakes. The third type of noise is 
that which occurs in bursts of a few seconds duration and might be confused with true micro-earthquakes.

The first type of noise limits the gain at which the instruments can be operated and thus determines the lower limit of recordable micro-earthquakes. This in turn determines the rate of micro-earthquake occurrence obtained. The approximate noise level for this type of noise at each station at about $20 \mathrm{cps}$ is indicated in Table 1 . These noise levels vary from about $0.05 \mathrm{mu}$ to $0.8 \mathrm{mu}$ amplitude of ground motion. Generally speaking, recording on crystalline basement rocks gave low noise

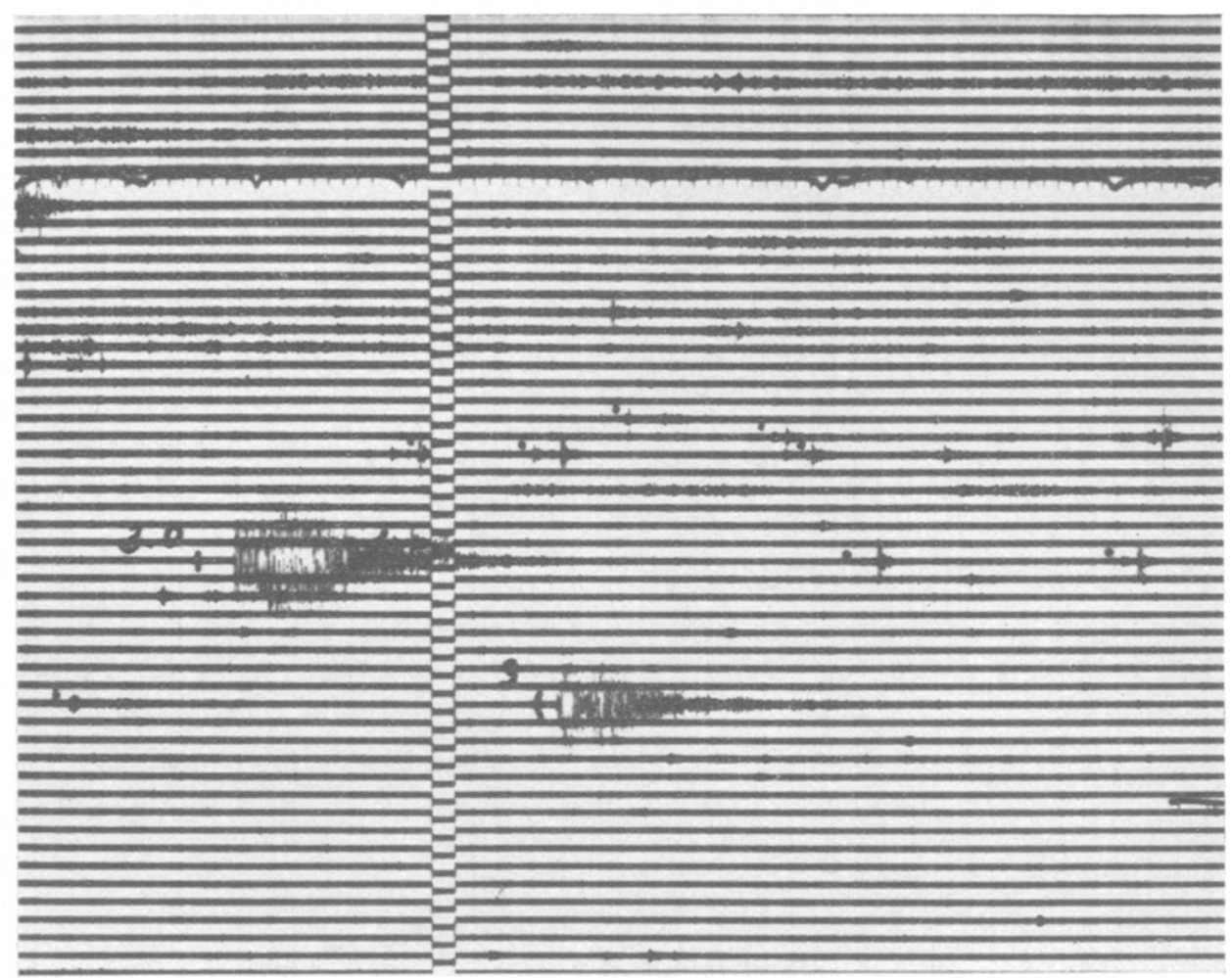

Fra. 4. Seismogram illustrating two micro-earthquakes and numerous sonic events with arrivals that could be confused with $P$ and $S$ waves of micro-earthquakes.

levels while recording on sedimentary rocks, especially unconsolidated sediments, gave high noise levels. Sources of the second type of noise are wind, streams, trains, cars, airplanes, etc. Sources of the third type of noise are explosions, sonic booms, cannon bursts, slamming of car doors, falling object, etc. Most of these can be easily distinguished from earthquakes; however, in certain cases their appearance is almost identical with that of micro-earthquakes (see Figure 4), and hence they require a considerable amount of experience to be distinguished with a single instrument. An attempt was made, whenever possible, to have two or more instruments recording simultaneously at two sites so events could be checked from one instrument to another. The study of events recorded on the array of five instruments 
recording in Cajon Pass was invaluable in distinguishing cannon bursts which produced sonic waves with the appearance of micro-earthquakes with very convincing apparent $P$ and $S$ arrivals (see Figure 4). As a result of very careful study of the records, we have gained confidence that artificial noises have not been identified as micro-earthquakes.

Estimation of magnitudes. The micro-earthquake magnitudes cited in this paper are only approximate and are based on determination of amplitude-versus-distance curves for the instruments used in this study and on comparison of trace amplitudes with magnitudes determined by standard Wood-Anderson torsion seismometers. The definition of magnitude arrived at is as follows:

$$
M=\log A+\log \left(G_{\text {wa }} / G_{20}\right)-\log A_{0}+\log A_{20}
$$

where

$A=$ Amplitude measured on record in millimeters

$G_{\text {wa }}=2800=$ Gain of Wood-Anderson torsion seismometer

$G_{20}=$ Gain of instrument with response peaked near $20 \mathrm{cps}$

$A_{0}=$ Amplitude of magnitude zero event, in millimeters, recorded on WoodAnderson torsion seismometer, as given by Richter (1958)

$A_{20}=$ Amplitude-versus-distance correction for $20 \mathrm{cps}$ seismic waves, determined empirically as follows: $\log A_{20}=0.55$ at $5 \mathrm{~km}, 1.00$ at $8 \mathrm{~km}, 1.50$ at 15 $\mathrm{km}, 1.70$ at $20 \mathrm{~km}$, and 1.80 at $24 \mathrm{~km}$.

The smallest earthquakes identified in this study have $S-P$ times of about 0.6 seconds and magnitudes of about -1.3 ; however, the sampling for such small events is very poor. The sampling of the hemispherical volume of $24-\mathrm{km}$ radius is complete only for magnitudes greater than about +0.5 . For purposes of comparison with plots of cumulative numbers of events versus magnitudes (Allen et al. 1965), it is convenient to estimate the magnitude to which the observed rate of microearthquake occurrence would correspond if the sampling were complete. This magnitude is estimated to be about zero for this study; that is, if a plot of the cumulative numbers of events within $24 \mathrm{~km}$ of a given site versus magnitudes of these events is extended to $M=0$, the number obtained should correspond roughly to the rate of micro-earthquake occurrence obtained in this study.

Stationarity of seismicity. The rate of micro-earthquake activity determined from a two-day sample will, of course, vary from sample to sample at a given site. For example, at Obsidian Butte during the first two-day period of operation a rate of 128 earthquakes per day was obtained, but later occupation of the site for a period of five days indicated an average rate of about 32 per day. Results from sites occupied for long periods of time indicate that for two-day intervals the rate could vary by more than a factor of ten, but that usually a two-day interval was sufficient to give an approximate indication of the local level of micro-seismicity.

The relative stationarity of seismicity is illustrated (Figure 5) by plots of cumulative numbers of events versus cumulative noise-free recording time for several sites: Lake Hughes, Lone Pine Canyon, Devil Canyon, and Horse Canyon. For 
Lake Hughes the rate is very low, and the small number of events probably is not an adequate sample despite more than one year of recording at this site. Nevertheless, the events are not bunched up, and any two-day recording period would have indicated a low level of seismicity. For Lone Pine Canyon the average rate over several months was 2 micro-earthquakes per day (uncorrected for relatively high noise level; see below), although the range for particular two-day recording intervals was from 0 to about 10 per day. For Devil Canyon the average rate over several months was 3 micro-earthquakes per day (uncorrected), and the range for particular two-day recording intervals was from zero to about 30 earthquakes per day. For

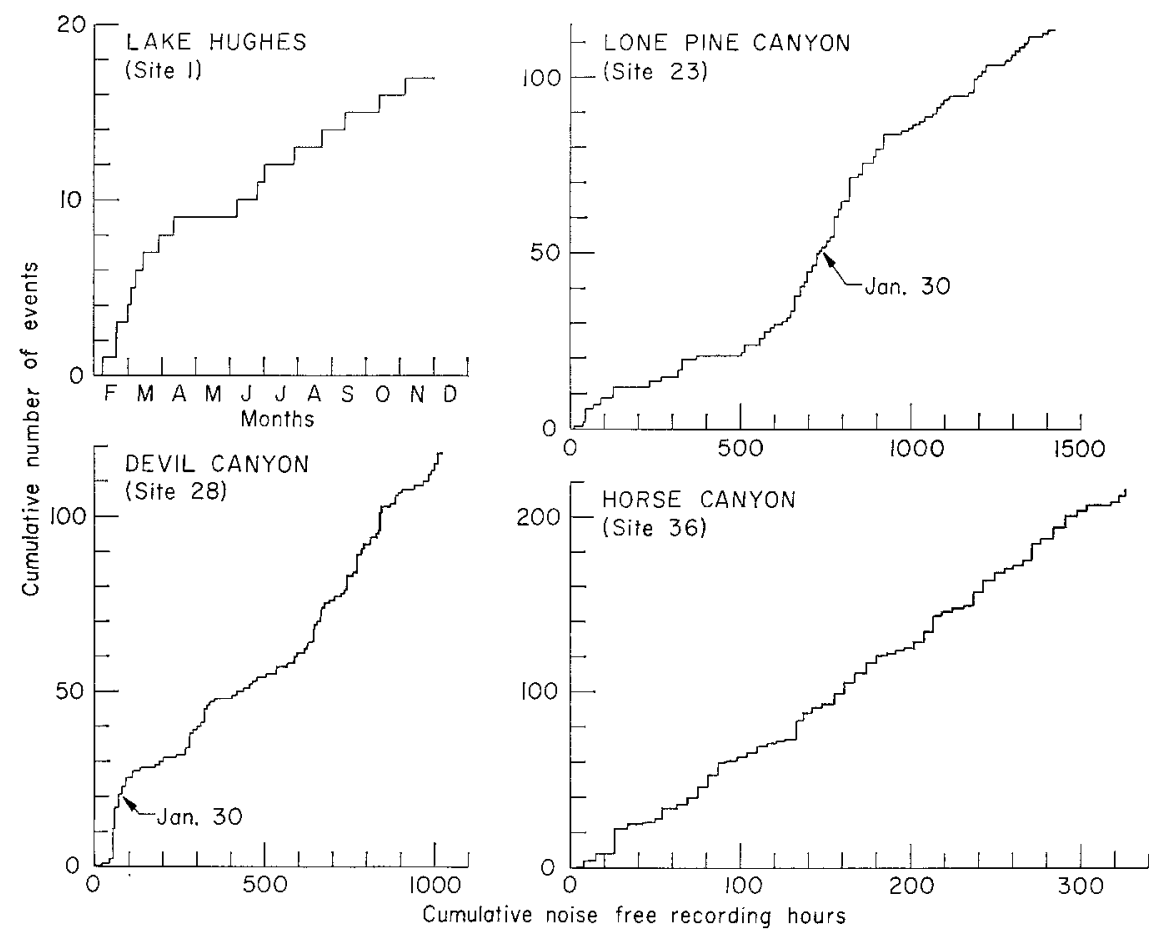

Fig. 5. Cumulative numbers of micro-earthquakes plotted against time for four sites oceupied in this study. Note variations in vertical and horizontal scales.

Horse Canyon the average rate was 16 events per day and the range for particular two-day recording intervals was from about 9 per day to about 18 per day. For Obsidian Butte the average rate was 37 micro-earthquakes per day (uncorrected) with the rate for particular two-day samples ranging from 12 per day to 64 per day.

\section{Results of THE SURVEY}

The results of the survey in terms of rates of micro-earthquakes per day with S-P times less than 3 seconds are shown in Table 1 and Figure 3. Table 1 also gives other pertinent data such as the recording dates and times, location of recording points, number of recording hours, number of noise-free recording hours, approximate background noise level and the type of rock on which the geophone was 
located. The actual rates observed were in some cases multiplied by a correction factor if the site had a particularly high noise level. In such cases the rate cited is followed by $(2 \times),(3 \times)$, etc. indicating the correction factor used.

The rates range from near zero to as high as $128(2 \times)$ per day for events which were not obviously aftershocks of preceding larger shocks. For events which were aftershocks occurring within a few days of the main event, (footnoted in Table 1) measured rates were as high as $2400(8 \times)$ per day. The recording sites are grouped according to province, and the results are discussed below.

Hollister-Parkfield-Cholame sector. This segment of the San Andreas fault zone in the central Coast Ranges was moderately active during the test period, although only the ends of the segment were sampled. A six-day survey was carried out near Hollister (Grass Valley, site 26) in order to obtain a micro-earthquake rate in an area of known creep along the San Andreas fault. The rate of suficial creep here has been relatively uniform in recent years, averaging $1.5 \mathrm{~cm} / \mathrm{yr}$ (Tocher, 1960; Meade, 1965), and small felt earthquakes are not uncommon in this area. The measured rate of two micro-earthquakes per day at Grass Valley is moderate but not nearly as high as a number of other areas along the fault in southern California where creep apparently is not taking place, at least as slippage along a discrete plane at the surface.

Southward toward the Parkfield-Cholame area, triangulation data as well as geodimeter observations (Hoffman et al, 1966) indicate continued but gradually decreasing creep along the fault. Whitten (1960) computed a slippage rate of 0.3 $\mathrm{cm} / \mathrm{yr}$ at Cholame, although no field evidence of this had been observed until recently. Micro-earthquake measurements at five localities in the Parkfield-Cholame area during November and December of 1965 gave rates averaging about one event per day.

The Parkfield-Cholame area was shaken on 28 June 1966 by a moderate earthquake $(M=5.6)$ that was associated with small but surprising right-lateral displacements along more than $35 \mathrm{~km}$ of the San Andreas fault. This was subsequent to our principal micro-earthquake survey of the region, but similar measurements made here one day after the earthquake (site 55) indicated rates of more than 2000 events per day. It is significant that a one-day recording in the epicentral area (site 53) seven days before the earthquake showed no observable micro-earthquake activity. Obvious foreshocks commenced several hours prior to the main event (McEvilly, 1966), but evidently this premonitory activity did not extend earlier as much as seven days, at least near Parkfield. The reason that we had revisited the Parkfield area at this particular time was because fresh enechelon cracks-possibly indicative of accelerated creep-had recently appeared along the San Andreas fault here (Allen and Smith, 1966), and we were anxious to see if they were associated with a corresponding increase in micro-earthquake activity. The answer appears negative.

The Parkfield-Cholame area has been the site of several moderate-sized earthquakes in historic times, in $1901(M=6), 1922\left(M=6 \frac{1}{2}\right), 1934(M=6.0)$, and $1966(M=5.6)$. It is believed that the northernmost extent of ground breakage during the great 1857 earthquake was near Cholame.

Cholame-Valyermo sector. This central section of the San Andreas fault, which is 
thought to be essentially the same segment that broke during the great 1857 earthquake (Wood, 1955; Allen et al, 1965), is characterized by minimal micro-earthquake activity. Indeed, none of the sites along the fault northwest of Frazier Park (site 14) recorded any definite events during the sample periods despite their location in the Carrizo Plain region that is typically illustrated in textbooks as the most "geologically active" segment of the fault. The Frazier Park instrument did record a few micro-earthquakes, but these were probably from the nearby southern end of the aftershock area of the 1952 Kern County earthquakes rather than from the San Andreas fault zone. Although most of these sites were occupied for only two days, the group of sites southeast of Frazier Mountain centered near Lake Hughes

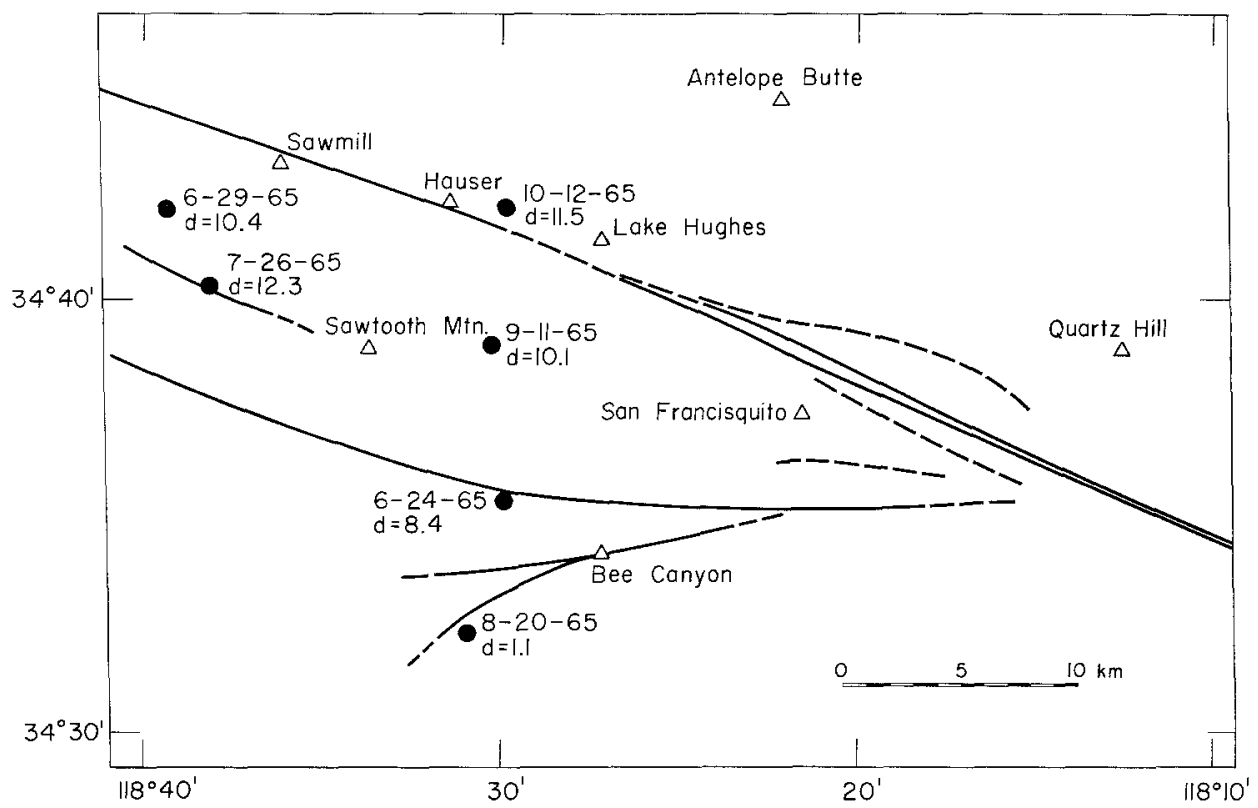

FIG. 6. Map of the Lake Hughes array and epicenters of located earthquakes, FebruaryNovember, 1965. Location of area is shown in Figure 3. Open triangles are seismometer sites (Table 1); depths are in kilometers.

(site 1) was occupied for a much longer time and provides the most convincing argument for relative quiescence along this central segment of the San Andreas fault.

The Lake Hughes area, $65 \mathrm{~km}$ northwest of Pasadena, was chosen as the first area in which to test the micro-earthquake instruments because, in addition to its proximity to Pasadena, the San Andreas fault is well-defined and "typical" in this area, and firm crystalline rocks occur on both sides of the fault zone. The initial Lake Hughes site was established virtually within the fault zone, and the seismograph here recorded for more than one year between November 1964 and February 1966. Seven additional portable instruments located in a $20 \times 40 \mathrm{~km}$ area surrounding Lake Hughes (sites 2-9) constituted an array that was completed during the middle part of 1965 (Figure 6).

Careful examination of records that have been collected from this array over a period of more than one year indicate without question that this is an exceptionally 
quiet area despite its location athwart an "active" segment of the San Andreas fault; that is, geological features indicating very recent fault displacements are abundant throughout this segment (Wallace, 1949). Records of the Lake Hughes station for 152 days between February and November of 1965 were painstakingly analyzed, and only 17 events with $S-P$ times of less than 3 sec could be recognized during this interval, and some of these were probably explosions. This represents an average of 1 micro-earthquake every 9 days, and these events were relatively uniformly distributed so that none occurred within 4 days of another. Of these 17 events, only 6 were large enough or recorded on enough other stations of the array to get hypocentral locations, and these are shown in Figure 6. Clearly the San Andreas fault itself is not the source of most of these shocks, all but one of which were along the northeastern flank of the Ventura basin southwest of the fault zone.

It is instructive to compare the rates of micro-earthquake activity as measured during these relatively short time periods with the over-all level of seismicity as reflected in the records of the previous 29 years for which good seismograph coverage has existed in southern California (Allen et al, 1965). Two types of comparison are possible: In a gross way, the map of strain release compiled by Allen et al, (1965) can be used simply to portray areas of high and low activity during this 29 -year period. Or, secondly, it is possible to make a quantitative extrapolation of expected micro-earthquake activity based on frequency-versus-magnitude curves (recurrence curves). If the recurrence curve for a given area, based on the 29-year record of shocks of $M \geqq 3.0$ is extrapolated as a cumulative curve down to the magnitude 0 level, one can estimate the frequency of earthquakes of $M>0$ that should have occurred during this time if the simple frequency-versus-magnitude relationship is valid. As explained above this should roughly correspond to the rate of micro-earthquake activity obtained in this study. If one extrapolates the 29 -year recurrence curve for all events within $24 \mathrm{~km}$ of Lake Hughes, one would expect 0.2 shocks of $M>0$ per day, whereas the rate of micro-earthquake activity observed in the present study was 0.1 . This is considered remarkably good agreement and suggests that the level of micro-earthquake activity in this area could have been grossly predicted simply by looking at the larger earthquakes that occurred during a period of several tens of years.

The above results, along with results from the other stations along this segment of the San Andreas fault, suggest that the entire length of the fault which ruptured in 1857 is now quiet. However, this was obviously not true during and following the 1857 shock nor during the innumerable great earthquakes which preceded this, which only emphasizes once again the problems in attempting to extrapolate records of a few days or years to major events which apparently happen at intervals of hundreds of years.

Subsequent to the operation of the Lake Hughes array, a permanent microearthquake station has been established at Sawmill Mountain Ranch (near site 6) in order to continuously monitor micro-earthquake activity along this quiet segment of the fault. We particularly desire to test whether the fault is subject to occasional increases in activity and whether high micro-seismicity might precede the next large earthquake here. The Parkfield earthquake of 28 June 1966, discussed in the previous section, was not associated with any increases in activity at the Sawtooth Mountain Ranch station, $200 \mathrm{~km}$ southeast along the fault. 
Inasmuch as the quiet section of the fault that extends about $150 \mathrm{~km}$ each way from Frazier Park corresponds approximately to the segment of the San Andreas system that trends more easterly than adjoining segments, our observations tend to confirm the idea that this section of the fault is temporarily "locked." Certainly the abundant thrust faulting adjacent to the fault in this area indicates that strain release is very complicated, possibly requiring greater stress differences for rupture than in adjacent areas. Corresponding to the observed absence of micro-earthquakes, there is also little evidence of creep along this part of the fault; geodimeter observations (Hoffman et al, 1966; Hoffman, personal communication) indicate virtually no creep between Carrizo Plain and Valyermo nor does the one triangulation are that crosses the fault near Lake Hughes (Meade, 1965). Whether or not regional shear is accumulating across the entire fault system in this segment, however, is a question that has not been answered by existing measurements. It is difficult to believe that large shear can be taking place both north and south of this segment without increasing the strain across the zone in this region. Despite the almost complete absence of micro-earthquakes in the Cholame-Valyermo segment, and indeed partly because of this, we stand by the earlier position (Allen et al, 1965) that this segment of the San Andreas fault is among the most likely to have a great earthquake.

San Andreas and San Jacinto faults in the Cajon Pass area. Micro-earthquake activity associated with the San Andreas fault system increases abruptly southeast from Valyermo into the Cajon Pass area, where the San Jacinto fault diverges southward from the rest of the system. An array of 5 instruments was operated in the Cajon Pass area for about 4 months, giving well-documented rates of $4(2 \times)$ microearthquakes per day at Lone Pine Canyon (site 23) and 6 (2X) per day at Devil Canyon (site 28). Using the array, 23 events were located during this period, and their locations are shown on Figure 7. During the first two months, most of the activity was concentrated northwest of San Sevaine (site 38), in the area of a group of east-trending fractures representing the eastern end of the San Gabriel fault system. Later in the period the activity shifted southeastward. It is perhaps significant that those events close to the San Andreas fault have an average depth of focus close to $11 \mathrm{~km}$, whereas those farther southwest are consistently shallower. Although one might make an argument for an alignment of epicenters along the San Andreas fault (which is certainly a wider zone than the line of Figure 7 suggests), the epicenters southwest of the San Jacinto fault are more randomly distributed in a manner similar to that of typical earthquakes of magnitude $3-4$ throughout southern California (Allen et al, 1965).

The study of shocks of magnitude 3 and greater during the past 29 years is consistent with the micro-earthquake data in that it would predict a relatively high rate of activity in the neighborhood of Cajon Pass as compared to the section of the fault northwest of Valyermo. However, it is interesting to note that the 29-year sample would not have predicted the high observed activity at Lone Pine Canyon (site 23) and Table Mountain (site 10). A felt earthquake near Table Mountain in November 1965 as well as the relatively high rate of micro-earthquake activity appears to represent a recent increase in seismicity in this region. There is no seismic evidence, on the other hand, that this increase in activity is necessarily related to the San Andreas fault itself. 
That fault creep is not now taking place along a discrete plane at the surface in this segment is indicated by the absence of offsets in numerous cultural features (particularly buildings) that cross the San Andreas and San Jacinto faults, as well as by several closely spaced survey lines. Nevertheless, recent geodimeter measurements (Hoffman, personal communication) suggest that distributed right-lateral shear has taken place very recently across the San Andreas zone, increasing southeastward from nil in the area of Valyermo to values of several $\mathrm{cm} / \mathrm{yr}$ near San Bernardino. Thus again we have an example of high micro-earthquake activity seemingly being closely correlated with contemporary deformation along the fault.

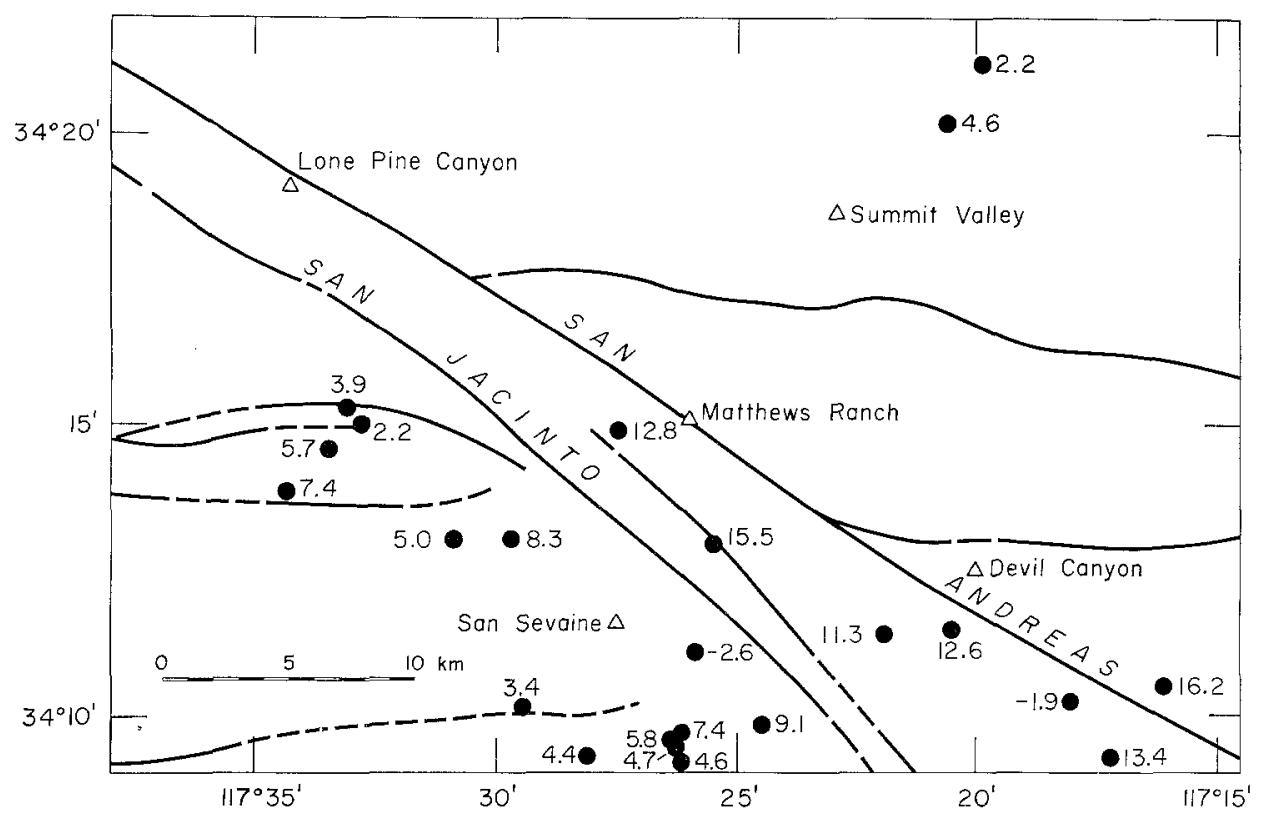

Fig. 7. Map of the Cajon Pass array and epicenters of located earthquakes, January-April, 1966. Location of area is shown in Figure 3. Open triangles are seismometer sites (Table 1). Numbers are focal depths in kilometers.

San Andreas fault zone: Cajon Pass to Desert Hot Springs. In southeastern California the San Andreas fault system splits into a number of branches, the two principal members of which are the San Jacinto and Banning-Mission Creek faults. The San Jacinto fault is discussed separately in a later section. The Banning-Mission Creek system-commonly thought of as "the" San Andreas fault-is so named because in the San Gorgonio Pass area, west of Desert Hot Springs, it comprises two distinct members that coalesce toward the southeast to form the eastern structural boundary of the Salton depression. In the San Gorgonio Pass area, both the Banning and Mission Creek faults become east-trending features that are even more complicated by thrusting than is the San Andreas fault zone near Frazier Park. In contrast to the Frazier Park area, however, the fault zone in San Gorgonio Pass is characterized by both high micro-earthquake activity and frequent felt earthquakes. That much of this activity is related to thrusting is indicated not only by the surficial geology but also by seismic first-motion studies (Dehlinger, 1952). 
At Pine Bench (site 2), 2 micro-earthquakes per day were recorded during a typical 3-day period, although 5 days later-following a magnitude 5.0 shock nearby - the rate was more than 50 per day. The measured rate of 6 events per day at Desert Hot Springs (site 30) may reflect continuing after-shock activity of the magnitude $6 \frac{1}{2}$ earthquake here in 1948 , inasmuch as the $24 \mathrm{~km}$ circle around the site includes virtually the entire area of aftershock activity at that time. In order to test the reasonability of this hypothesis, the strain-release envelope given by Richter et al, (1958) was extrapolated to the time of our observations in 1965. On this basis alone, one would have expected 4 shocks of equivalent $M=0$ per day within the aftershock area. Thus the hypothesis of continuing aftershock activity seems reasonable, although it is dependent on the definition of the term "aftershock".

The relatively high micro-earthquake activity of the Cajon Pass-Desert Hot Springs segment of the San Andreas fault system again agrees with expectations based on the preceding 29-year sample of earthquakes greater than magnitude 3 and might have been predicted solely on that basis.

San Andreas fault zone: Desert Hot Springs to the Mexican border. This segment of the Banning-Mission Creek fault is similar to the central segment of the San Andreas fault in that most of it is clearly delineated by geological features of very recent displacement, yet its micro-earthquake activity is nil. Neither the Painted Canyon nor East Mesa instruments (sites 31, 49) recorded any definite events with $S-P$ times less than 3 seconds despite their locations virtually athwart the fault. Southeast of the Salton Sea, little surficial evidence of the fault is visible because of very recent lake deposits and sand dunes, but geophysical evidence leaves little doubt of its continuity at least as far as the Mexican border ( $\mathrm{S}$. Biehler, personal communication). The absence of micro-earthquake activity in this segment agrees well with the preceding 29 -year sample.

San Jacinto fault zone: Cajon Pass to the Mexican border. The San Jacinto fault is the most active fault in southern California on almost all counts: micro-earthquakes, earthquakes of magnitude 3.0 and greater during the past 29 years, and large earthquakes in the magnitude 6-7 range in historic times. Furthermore, the geologic features of Quaternary displacement are fully as impressive, in some segments, as those of the San Andreas fault in central California. Only in the category of truly great earthquakes does the evidence for "activity" break down; none has occurred in this sector within the historic record, although one might well argue that the moderate-sized earthquakes are sufficiently frequent to relieve accumulating strain without the necessity for still larger events (Allen et al, 1965). The San Jacinto fault is relatively well defined southeast from Cajon Pass to the Borrego Valley area (near site 35), but farther southeast it splits into a number of more poorly defined branches (i.e., Imperial, Superstition Hills, Superstition Mountains faults), all of which are herein considered part of the San Jacinto fault zone.

With the exception of the northwestern-most station (site 13), the average rate of micro-earthquake activity along the fault zone is more than 10 events per day, ranging up to about 75 per day at Obsidian Butte (site 32). Although Obsidian Butte is a Quaternary volcanic plug associated with marked local thermal anomalies, the distribution of micro-earthquakes in this area leads us to believe that these 
earthquakes represent the same regional stress system as elsewhere, and are not solely the result of localized volcanic or thermal activity at depth. Several of the sites along the San Jacinto fault, such as Obsidian Butte and Horse Canyon (site 36), have been occupied by our micro-earthquake instruments for extended periods or at several different times, so we feel particularly confident of the statement of high micro-earthquake activity along this fault zone. Again this result could have been predicted by the results from the 29 -year sample of events with $M \geqq 3.0$.

That strain is indeed taking place across the San Jacinto fault is independently indicated by geodetic data: Whitten $(1956,1960)$ shows $8 \mathrm{~cm} / \mathrm{yr}$ of right-lateral shear across the entire width of the Imperial Valley and suggests that about onehalf of this could be accounted for by discrete slippage on the Imperial fault. Although no field evidence of gradual slippage has been observed here, displacement of about $1 \frac{1}{2} \mathrm{~cm}$ apparently took place along the fault in association with a magnitude 3.6 earthquake on 4 March 1966 (Brune and Allen, in press). Micro-aftershocks of this earthquake were recorded at Superstition Hills (site 50), $24 \mathrm{~km}$ away, and averaged 50 events per day during the two days following the shock.

Perpendicular profile: Pacific Ocean to the Arizona border. A $300 \mathrm{~km}$ micro-earthquake profile across southern California perpendicular to the major fault zones was measured in order to see if regions adjacent to the San Andreas fault zones might likewise be areas of high activity. Assuming that the Elsinore fault is part of the San Andreas system, no other major faults that would be considered "active" from geologic evidence are crossed by this profile.

The profile indicated no local micro-earthquake activity in the batholithic rocks of the Peninsular Ranges at the southwest end of the line, but high activity near the Elsinore and San Jacinto faults. Whether or not the rest of the Elsinore fault shares this local high activity has not as yet been tested. As pointed out in a previous section, the Banning-Mission Creek fault is presently quiet where crossed by this line, although it must be considered a very "active" fault on geologic grounds. Northwestward into the Mojave Desert micro-earthquake activity remains minimal. All in all, micro-earthquake activity along this profile is very nearly what would have been predicted from the earlier 29-year record, and indicates that in a gross sense the micro-earthquake activity is concentrated in regions near active faults.

1952 Kern County earthquake area. Micro-earthquake activity was observed at Bear Mountain (site 40), near the concentration of aftershock activity at the northeast end of the 1952 break, in order to see if activity remains high. The observed $19(2 \times)$ micro-earthquakes per day compares to about 50 equivalent $M>0$ shocks per day that might be predicted on the basis of extrapolation of Benioff's (1955) strain-release curve for the southeastern block. Thus the hypothesis that the high activity here represent continuing aftershock activity from the 1952 event appears reasonable. That there is some danger in this long-term extrapolation, however, is indicated by the fact that after 100 years one would still expect about six events per day. Were this kind of extrapolation to be valid, numerous micro-aftershocks should still be taking place along the San Andreas fault in the area of the great 1857 earthquake (assuming a corresponding high aftershock activity), where there is instead minimal micro-earthquake activity today. 
Central Mojave Desert earthquakes of September 25-26, 1965. Two shocks of magnitude $5 \frac{1}{4}$ (CGS: 5.0, 4.6) occurred near Ludlow, in the central Mojave Desert, on 25-26 September 1965. A portable micro-earthquake instrument had been set up in the area at the time of the second shock and recorded aftershocks at the rate of $450(3 \times)$ per day for the following 10 hours. The instrument was about $28 \mathrm{~km}$ from the main center of activity and undoubtedly would have recorded many more shocks had it been closer.

Slate Mountain and Dixie Valley, Nevada. These observations, for only short periods of time, were made in order to compare our instrumental response with that used in the micro-earthquake study of Oliver et al, (1966) and to compare the known high micro-earthquake activity in the aftershock zone of the 1954 Fairview Peak-Dixie Valley earthquakes with that observed at various sites in California. The recordings at Slate Mountain (site 56) and Dixie Valley (site 57) both show background noise, and thus the instruments were operating at maximum useful gain. The rates obtained, 77 events per day at Slate Mountain and 37 at Dixie Valley are lower than those obtained by Oliver et al, (1966)-125 and 250 events per day respectively. The differences are certainly in part due to temporal changes in activity but are also in part due to the following factors:

(1) Only events with $S-P$ times less than 3 seconds were counted in this study whereas Oliver et al counted events with $S-P$ times less than 5 seconds. For Slate Mountain the rate obtained by Oliver et al using $S-P$ times less than 3 seconds would have been about 14 per cent less, i.e., about 108 per day.

(2) Relatively greater caution must be applied in identifying smaller earthquakes in California, inasmuch as cultural noise (Type 3) is more abundant here and the background noise level (Type 1) is somewhat higher, and in counting events in Nevada we applied the same caution required in California.

(3) The response curve used in this test had a peak response at $22 \mathrm{cps}$, whereas that used by Oliver et al peaked at $27 \mathrm{cps}$. This is not believed to have had a significant effect on the results.

Taking the above factors into consideration, we feel that the results of Oliver et al, (1966) for the Fairview Peak-Dixie Valley area should be divided by a factor of about two in order to make them comparable to our results for California. Thus the rate of micro-earthquake activity in the 1954 Nevada aftershock area was and continues to be much higher than in most areas along the San Andreas fault, and several times higher than the most active area along the San Jacinto fault. Obsidian Butte was the only station which gave a rate comparable to those observed in Nevada.

\section{Summary and Conclusions}

(1) Micro-earthquakes ranging in magnitude down to about $M=-1.3$ have been systematically recorded at more than 60 locations in southern California, particularly along the San Andreas fault zone. Records of more than 35,000 hours of noise-free recording have been analyzed and represent a considerably larger time sample than has been reported from previous studies of micro-earthquakes.

(2) Background noise level varies considerably throughout the region, ranging, at $20 \mathrm{cps}$, from $0.8 \mathrm{mu}$ ground amplitude to about $0.05 \mathrm{mu}$. Sites on crystalline rock far from sources of cultural noise are quietest giving noise levels averaging .05-.1 mu. 
(3) There is no indication of a uniform regional level of background micro-earthquake activity, at least down to the magnitude levels investigated in this study.

(4) Although two-day samples at a given site sometimes showed micro-earthquake rates varying by factors greater than 10 , the probability was high that the two-day sample reflected about the same level of activity as longer samples ranging from 5 days to 1 year.

(5) Observed rates of micro-earthquake activity in southern California vary by factors of as much as 400 from site to site, excluding aftershock sequences within a few days of the principal events. Although some regions and fault zones have consistently higher activity than others, the gross pattern is one of localized "hot spots." A profile of sites occupied transverse to the trend of major faults indicated a general concentration of activity near faults that would be considered active on geologic grounds.

(6) The San Andreas fault system, which shows clear geologic evidence of recent and presumably continuing displacements throughout its length, nevertheless exhibits great variations in current micro-seismicity in various segments. In particular, the $300-\mathrm{km}$ segment between Cholame and Valyermo which broke during the great 1857 earthquake, has virtually no measurable micro-earthquake activity. On the other hand, the San Jacinto fault, a major branch of the San Andreas system, has consistently high micro-seismic activity throughout most of its length.

(7) Along the San Andreas fault within and north of the Transverse Ranges, the segments with observed relatively high micro-earthquake activity correspond remarkably well with those segments where fault creep has been inferred from triangulation and geodimeter measurements. Similarly, the high micro-earthquake activity along the San Jacinto fault corresponds to an area where high strain rates have been indicated by geodetic studies.

(8) The regional pattern of micro-earthquake activity during the period of this study is grossly similar to the seismicity pattern of larger earthquakes during the 29-year period from 1933 to 1963 . This result agrees with that obtained by Oliver et al, (1966) for Nevada. This suggests that microseismic activity may be relatively stationary for periods of several tens of years. The historic record of great earthquakes in presently inactive parts of this same region, however, indicates that micro-seismic activity certainly will vary over periods longer than a few tens of years. Thus one must be cautious in extrapolating present activity into the future.

(9) The fact that in most localities the rate of micro-earthquake activity could have been roughly predicted by extrapolation of frequency-versus-magnitude curves from the 29-year record of larger shocks, suggests that micro-earthquakes in this region are related to the same physical causes as the larger events. Partly as a consequence of this correlation, it is a reasonable hypothesis that all of the microearthquake activity observed in this study can be attributed to aftershocks or aftershock swarms of preceding larger earthquakes, depending on the chosen definition of the word "aftershock."

(10) The present study has not uncovered any definite criterion based on microearthquakes which will be a quick panacea for the problems of earthquake prediction. It is significant that observed micro-earthquake activity was nil in the epicentral area of a $M=5.6$ earthquake on the San Andreas fault seven days before the event-an earthquake that was associated with surficial displacements along 
more than $35 \mathrm{~km}$ of the fault. Some minor surficial fault displacement had already taken place at the time of the micro-earthquake observation, and fault creep continued for several weeks after the main event. This same earthquake was associated with no observed change in the level of micro-seismicity at a site $200 \mathrm{~km}$ away along the same fault.

One phenomenon which may ultimately be useful in estimating earthquake hazard is the apparent correlation between the zone of faulting during the great 1857 earthquake and the zone of current minimal seismic activity, both for micro-earthquakes and larger events. For example, sections of active faults characterized by occasional very large earthquakes may, in the intervening periods, be characterized by extremely low seismicity, possibly due to some "locking" mechanism (e.g., 1857 earthquake zone), whereas sections of the fault characterized by lack of very large earthquakes may in turn be characterized by more-or-less continuous seismic activity on a smaller scale (e.g., San Jacinto fault zone).

\section{ACKNOWLEDGMENTS}

We are especially indebted to Mr. Franeis Lehner for supervision of the field program as well as for the design of most of the equipment. Mr. John Lower and Mr. Daniel Tanner carried out most of the actual field operation. Miss Gladys Engen assisted in the computations, and Mr. Paul Richards and Mr. David Jackson read many of the records. Initial operation of the micro-earthquake trailers was inaugurated under the direction of Dr. Frank Press.

The construction of the micro-earthquake trailers was supported by the Air Force Office of Scientific Research, Office of Aerospace Research, United States Air Force, under AFOSR contract number AF-49(638)-1337, and the entire field program was supported by National Science Foundation grant GP 2806 (Upper Mantle Project).

\section{References}

Allen, C. R. and S.W. Smith (1966). Parkfield earthquakes of June 27-29, Monterey and San Luis Obispo Counties, California: Pre-earthquake and post-earthquake surficial displacements, Bull. Seism. Soc. Am. 56, 966-967.

Allen, C. R., P. St. Amand, C. F. Richter and J. M. Nordquist (1965). Relationship between seismicity and geologic structure in the southern California region, Bull. Seism. Soc. Am. $55,753-797$.

Asada, T. (1957). Observations of near-by micro-earthquakes with ultra-sensitive seismometers, J. Phys. Earth 5, 83-113.

Benioff, H. (1955). Mechanism and strain characteristics of the White Wolf fault as indicated by the aftershock sequence, California Div. of Mines Bull. 171, 199-202.

Brune, J. N. and C. R. Allen, (in press). Displacement on the Imperial fault, March 4, 1966, Bull. Seismo. Soc. Am.

Bune, V. I. (1964). Attempt to predict the recurrence of strong earthquakes in the Vakhsh area of Tadzhikistan, in Voprosy Ingenernoy Seismologii, 9, Akad. Nauk SSSR Inst. Fiziki Zemli, Trudy 33 (200), 100-117.

Dehlinger, P. (1952). Shear-wave vibrational directions and related fault movements in southern California earthquakes, Bull. Seism. Soc. Am. 42, 155-173.

Hagiwara, T. (1964). Brief description of the project proposed by the earthquake prediction group in Japan, Proc. U.S.-Japan Conf. on research related to earthquake prediction problems, (Tokyo), 10-12.

Hoffman, R. B., D. Crice and J. Bennett (1966). Fault movement in California, 1959 to 1966 (Abstract), Trans. Am. Geophys. Un. 47, 166.

Isacks, B. and J. Oliver (1964). Seismic waves with frequencies from 1 to 100 cycles per second recorded in a deep mine in northern New Jersey, Bull. Seism. Soc. Am. 54, 1941-1979.

Lehner, F. and F. Press (1966). A mobile seismograph array, Bull. Seism. Soc. Am. 56, 889-898. 
Meade, B. K. (1965). Horizontal crustal movement in the United States. IUGG 2nd Symposium on Recent Crustal Movements, 13-25.

McEvilly, T. V. (1966). Parkfield earthquakes of June 27-29, 1966, Monterey and San Luis Obispo Counties, California: Preliminary seismic data, June-July, 1966, Bull. Seism. Soc. Am. 56, 967-971.

Oliver, Jack, Alan Ryall, James N. Brune, and David B. Slemmons (1966). Micro-earthquake activity recorded by portable seismographs of high sensitivity, Bull. Seism. Soc. Am. 56, 899-924.

Richter, C. F. (1958). Elementary seismology, W. H. Freeman and Co., San Francisco.

Richter, C. F., C. R. Allen and J. M. Nordquist (1958). The Desert Hot Springs earthquakes and their tectonic environment, Bull. Seism. Soc. Am. 48, 315-337.

Tocher, D. (1960). Creep on the San Andreas fault: Creep rate and related measurements at Vineyard, California, Bull. Seism. Soc. Am. 50, 396-403.

Wallace, R. E. (1949). Structure of a portion of the San Andreas rift in southern California, Bull. Geol. Soc. Am. 60, 781-806.

Whitten, C. A. (1956). Crustal movements in California and Nevada, Trans. Am. Geophys. Un. 37, 393-398.

Whitten, C. A. (1960). Horizontal movement in the earth's crust. J. Geophys. Res. 65, 28393844.

Wood, H. O. (1955). The 1857 earthquake in California, Bull. Seism. Soc. Am. 45, 47-67.

Seismological Laboratory

California Institute of Teghnology

Pasadena, California 91105

(Division of Geological Sciences Contribution No. 1422).

Manuscript received September 22, 1966. 